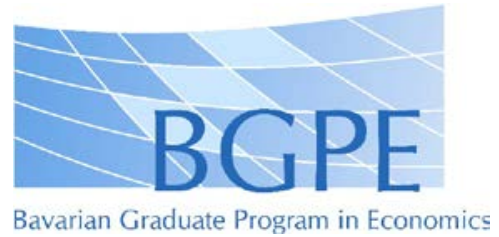

BGPE Discussion Paper

No. 162

\title{
Refinancing MFIs with Market Power: Theory and Evidence
}

\author{
Lutz G. Arnold \\ Benedikt Booker \\ Gregor Dorfleitner \\ Michaela Röhe
}

January 2016 


\title{
Refinancing MFIs with Market Power: Theory and Evidence*
}

\author{
Lutz G. Arnold ${ }^{\dagger}$ \\ Benedikt Booker \\ Gregor Dorfleitner \\ Michaela Röhe \\ University of Regensburg \\ Department of Economics \\ 93040 Regensburg, Germany
}

January 21, 2016

\begin{abstract}
This paper presents a model of the complete microcredit financing chain investor $\rightarrow$ MIV $\rightarrow$ MFI $\rightarrow$ micro-borrower, in which social-minded MIVs provide funds only to those MFIs which do not exploit their bargaining power towards micro-borrowers. The MFIs with the highest bargaining power do not use MIV capital, since eschewing their market power is most costly for them. Consistent with this prediction of the theoretical model, we find empirically that the net interest margin, as a measure of MFI market power, negatively affects the likelihood of using MIV finance. This lends support to the view that social criteria play an effective role in MIVs' investment policies, thereby also impacting MFIs' lending behavior.
\end{abstract}

JEL classification: G21

Keywords: microfinance, microfinance investment vehicles, social returns

\footnotetext{
${ }^{*}$ Financial support from the Deutsche Forschungsgemeinschaft (DFG) through grant AR 530/1-1 is gratefully acknowledged. We are also grateful to seminar participants at Freie Universität Berlin and CERMi.

${ }^{\dagger}$ Corresponding author. Tel +49 941943 2705; fax +49 941943 1971; lutz.arnold@ur.de.
} 


\section{Introduction}

Microfinance investment vehicles (MIVs) have become an increasingly important source of funds for (a subset of) microfinance institutions (MFIs). By now, more than one-hundred MIVs with assets under management of more than $\$ 8$ billion are active (MicroRate, 2013, 4). In the early stages of its development, the MIV sector was perceived as predominantly return-oriented, rather than socially motivated, and, therefore, as a threat to the double bottom line approach pursued by many MFIs (although considerable heterogeneity with regard to MIVs' social orientation was acknowledged; see, e.g., Goodman, 2006, 17). However, by now, almost all active MIVs endorse the Smart Campaign Client Protection Principles. Several MIVs have integrated measures of social performance into their investment appraisal techniques (De Corte, 2012, 3; MicroRate, 2013, 11). According to De Corte et al. (2012, 3-4), "[T]he 'double bottom line debate' that has been so strong for MFIs is now being passed to the MIV industry, resulting into much more attention devoted to how MIVs make sure that their investments are "socially responsible".

This paper investigates the role of MIV refinancing of MFIs both theoretically and empirically. We set up a model in which MFIs have bargaining power in the market for microcredit. There is an MIV that is socially motivated, in that it provides finance only to those MFIs which do not exploit their market power towards micro-borrowers. The larger MFI market power, the more costly it is not to use it. So the model predicts that those MFIs with the highest market power do not use MIV capital. We interpret eschewing market power as a proxy for other types of social lending behavior not contained in the model, which also benefit borrowers at the cost of lower profitability, such as increasing outreach beyond the profit maximizing level or targeting the poorest loan applicants. Consistent with the theoretical model, we find empirically that the net interest margin, as a measure of MFI market power, negatively affects the likelihood of using MIV finance. This is hard to reconcile with the traditional view that MIVs focus on relatively large, mature MFIs with an emphasis on financial as opposed to social returns. So we interpret our finding as valid evidence that social criteria play an effective role in MIVs' investment policies, which in turn affect MFIs' lending behavior in the market for microcredit. To paraphrase De Corte et al. (2012), the double bottom line debate has already arrived and is operative in the MIV industry.

The paper contributes to the theoretical microfinance literature by setting up a model of the complete financing chain investor $\rightarrow$ MIV $\rightarrow$ MFI $\rightarrow$ micro-borrower. Payments enforced with the use of non-pecuniary penalties by MFIs in informal credit markets are converted into enforceable financial claims by an MIV, which acts as a delegated monitor for its investors. The MFI-borrower relationship is modeled as in Rai and Sjöström (2013) (henceforth: "RS"; see also Rai and Sjöström, 
2004). We employ the version of their model with public repayment meetings despite individual liability and with mutual insurance via imperfect side contracting (RS, Subsection 3.3). So our model contributes to recent attempts to rationalize the maintained use of group lending schemes even when joint liability is abolished (as, e.g., by Grameen II; see also Giné and Karlan, 2014). As whether ot not MFIs make use of MIV capital is determined by their market power, our model relates to the heterogeneous set of theory papers which study the impact of competition in microfinance markets. The classic paper in this area is Hoff and Stiglitz (1997), which shows that with endogenous entry and scale economies an increase in subsidized loans may reduce the size of MFIs, raise the interest rate, and decrease the volume of microlending. Two important recent contributions are Dam and Chowdhury (2014) and De Quidt et al. (2013). Dam and Chowdhury (2014) analyze the effect of competition on repayment in a setup where credit agents may collude with borrowers against their MFI. De Quidt et al. (2013) show how a monopolistic MFI can raise its profit at the borrowers' expense by exploiting their social capital using joint liability loans.

Empirical studies of refinancing MFIs usually do not focus on MIVs in particular but on international suppliers of capital in general. Our paper contributes to this empirical literature by focusing on MIVs as suppliers of capital to MFIs. Given that MIVs have a more clearly defined mission than funds for which microcredit is but one alternative investment class, this approach is potentially fruitful in studying the impact of creditors' goals on MFI investment policies. Another contribution is our focus on market power, measured by the net interest margin, as a potential determinant of refinancing via MIVs. Mersland et al. (2011) investigate the impact of international subsidized and commercial debt on the social and financial performance of 379 rated MFIs. As measures of social performance they employ the average outstanding loan balance, a dummy variable indicating whether the MFI particularly targets female borrowers, and a categorical variable showing the MFI's preference for urban, rural, or mixed areas. The proxies for financial performance comprise the return on assets, operational self-sufficiency, and financial self-sufficiency. As for social performance, the results indicate a positive relationship between international subsidized debt and a focus on female borrowers.Furthermore, they identify a positive impact of international subsidized and commercial debt on rural areas. The findings show no significant relationship regarding the measures for financial performance. Mersland and Urgeghe (2013) analyze MFIs' access to international debt using pooled probit regressions. Besides a general investigation of the determinants of access to international debt, they put special emphasis on commercial vs. subsidized debt. In particular, their findings reveal a positive impact of the return on assets on the access to commercial debt and a negative impact of the portfolio at risk (30 days) and of a dummy indicating whether the MFI targets women. These results indicate that sources of commercial debt appreciate good financial 
figures and do not value social performance. In contrast, a women dummy has a positive influence on the access to international subsidized debt.

The paper is organized as follows. The model with perfect competition is presented and analyzed in Sections 2 and 3. Section 4 introduces MFI market power. The empirical analysis is in Section 5. Section 6 concludes.

\section{Model}

To set the stage for the theoretical analysis of the relation between market power and MIV refinancing, we start with a baseline perfect competition model of the microcredit financing chain investor $\rightarrow$ MIV $\rightarrow$ MFI $\rightarrow$ micro-borrower. There are several microcredit markets with MFIs making group loans with public repayment. The MFIs active in these markets borrow from an MIV, which acts as a delegated monitor for investors.

Projects

There is a continuum of length one of microfinance markets, with a continuum of length $l(>0)$ of micro-borrowers in each market. Each micro-borrower is endowed with one indivisible investment project, which transforms one unit of input into $h(>0)$ units of output if the project succeeds. The success probability in each market is determined by a market-specific shock: in a proportion $q(0<q<1)$ of the markets ("good markets"), the success probability is $p$ (where $0<p<1$ ); in the other $1-q$ ("bad") markets, the probability is zero. Conditional on the local shock, returns are independent. So the probability that two borrowers in a good market both fail is $(1-p)^{2}$. There is one MFI per market, which is specialized in making micro-loans in this market and not in others. The MFI makes individual liability loans of size unity to the micro-borrowers before it becomes known whether the market is good or bad. Whether they are active in a good market or in a bad market is contractible between MFI and borrower. The presence of the market-wide shocks implies that the MFIs' loan portfolios are risky, so that refinancing the loans is a non-trivial contracting problem. Apart from these shocks, the microcredit markets are as in RS (Subsection 3.3).

MFIs

The contract entails either private or public repayment. This formalizes the idea that the formation of groups in microfinance programs and group meetings may serve a useful purpose, even though there is no joint liability, by giving borrowers the opportunity to mutually insure themselves via informal side contracts. Given individual liability, a loan with private repayment is a standard loan. In the case of public repayment, pairs of borrowers who receive a loan form groups. They tell 
the MFI whether they can individually repay their loan or not simultaneously and in public. We focus on the case of imperfect side contracting. That is, peers can side-contract to help each other repay in case one borrower says she can repay and the other one says she cannot. Given public repayment, payoffs can be made contingent on the repayment decisions, both in the loan contracts offered by the MFI and in the side contracts. The outcome of investment projects, by contrast, is not contractible either in the loan contracts or in the side contracts.

As in Diamond (1984), the MFI has to use non-pecuniary penalties in order to enforce repayment. In addition, there is a pecuniary transaction cost per loan needed to process payments in good markets. Since borrowers in bad markets are unable to repay, the transaction cost does not apply to loans made in markets which turn out to be bad. For simplicity, both the size of the penalty $C$ $(>0)$ and the transaction cost $t(\geq 0)$ are exogenous and independent of whether they apply to a loan with private or with public repayment. ${ }^{1}$

The fact that each local market is subject to a market-wide shock means that, even though the MFIs are well diversified within their local market, their loan portfolios are risky: by the law of large numbers, a proportion $p$ of the projects succeed in a good market; but with probability $q$ the market turns out abd and all projects fail. In the baseline model, we assume that MFIs have no market power and no equity. So they offer the contract that maximizes borrower expected utility subject to the constraint that they break even. Section 4 introduces MFI market power to the model.

MIVs

In order to investigate the determinants of MFI access to MIV capital, we assume that MFIs get loanable funds from an MIV. The relationship between the MIV and the MFIs is characterized by a costly state verification problem as in Gale and Hellwig (1985) and Williamson (1986): in order to verify ex post whether an MFI is active in a good market or a bad market, the MIV has to pay a monitoring cost $\gamma(>0)$. Since the MFIs' loan portfolios are risky, incentive compatibility requires that the MIV makes use of the monitoring technology if an MFI declares default. We focus on deterministic monitoring and assume that the MIV has the opportunity to commit ex ante to use the monitoring technology in case of default. Given that the MFIs have no equity, the MIV's expected return is the difference between the expected return on the funds it lends to the MFIs and the expected state verification cost per MFI.

The MIVs get their money from investors, whose supply of funds is perfectly elastic at the rate of return $\rho(\geq 0)$. Since the MIV refinances MFIs in all the local markets, due to the law of large

\footnotetext{
${ }^{1}$ The model yields qualitatively identical results for any non-negative private versus public transaction cost differential and similar results with transaction costs for all loans.
} 
numbers, the return on its loan portfolio is safe. So the contract between the MIV and the investors stipulates a fixed return $\rho$.

To avoid case distinctions, let

$$
h>2 \Delta,
$$

where

$$
\Delta \equiv \frac{1}{p(2-p)}\left[\frac{1+\rho+\frac{(1-q) \gamma}{l}}{q}+t\right] .
$$

It will turn out that $\Delta$ is the equilibrium contractual public repayment on an MFI loan, so that (1) ensures that the payoff on successful projects exceeds the contractual repayment on two MFI loans and mutual insurance in borrower groups via side contracting is feasible.

\section{Equilibrium}

The model is solved backwards, starting with the MFI-borrower contracting problem. We first consider public repayment and private repayment separately. We then turn to the MIV-MFI relationship and compare the two repayment modes.

\section{Public repayment}

Since we abstract from MFI market power for now, the MFIs offer optimal contracts to the microborrowers subject to their zero profit constraint. Since borrowers in bad markets are unable to repay and whether a market is good or bad is contractible, it is optimal not to impose a penalty on borrowers in bad markets. Let $1+r^{*}$ denote the contractual repayment for each borrower in a good market. Since borrowers in bad markets cannot repay, in order to break even, a contract must induce successful borrowers in good markets to repay. We assume that if both group members decide to repay, then each repays $1+r^{*}$, while repayment is $2\left(1+r^{*}\right)$ if the peer does not repay. Since the peer's project is also successful with probability $p$, a borrower's conditionally expected repayment in a good market is $p\left(1+r^{*}\right)+(1-p) 2\left(1+r^{*}\right)$. The borrower's incentive compatibility constraint (ICC) requires that the expected penalty $(1-p) C$ is no less than this expected repayment, i.e.,

$$
(1-p) C \geq p\left(1+r^{*}\right)+(1-p) 2\left(1+r^{*}\right)
$$

Her participation constraint $(\mathrm{PC})$ is that the expected payoff in a good market is non-negative:

$$
p^{2}\left[h-\left(1+r^{*}\right)\right]+p(1-p)\left[h-2\left(1+r^{*}\right)\right] \geq(1-p)^{2} C .
$$


Due to the law of large numbers, the proportion of successful borrowers is equal to $p$ in each good market. So the MFIs' repayment conditional on being located in a good market

$$
1+\rho^{*}=p(2-p)\left(1+r^{*}\right)
$$

is safe.

As noted by RS, it does not make a difference whether the public repayment loan involves joint liability, as borrowers agree to insure themselves anyway. This equivalence would break down in a setup which takes care of the social tensions caused by joint liability.

\section{Private repayment}

With private repayment, the borrower's ICC requires that the penalty induces her to repay when her project succeeds:

$$
C \geq 1+r^{*}
$$

Her PC is

$$
p\left[h-\left(1+r^{*}\right)\right] \geq(1-p) C .
$$

The MFIs' safe repayment in a good market is

$$
1+\rho^{*}=p\left(1+r^{*}\right)
$$

\section{Refinancing microfinance}

Next, consider the MIV-MFI contracting problem. The contract specifies a repayment, $1+\hat{r}$ say, per dollar lent. If the MFI lends in what turns out to be a bad market, it goes bankrupt. Given zero liquidation value and zero equity, the MIV cannot extract a positive payment from a bankrupt MFI. Incentive compatibility requires monitoring when the MFI does not repay $1+\hat{r}$. So the MIV receives a repayment $1+\hat{r}$ per dollar lent in good markets and pays $\gamma / l$ per dollar lent in bad markets. Since the MIV diversifies across local markets, the average repayment per loan net of the monitoring cost

$$
1+\hat{\rho}=q(1+\hat{r})-(1-q) \frac{\gamma}{l}
$$

is safe due to the law of large numbers.

The MIV acts as a delegated monitor (cf. Williamson, 1986). As it generates a certain cash flow, intermediation is costless (cf. Williamson, 1986, 169). The MIV borrows from the investors at interest $\rho$ and repays with certainty. 
Zero profit for the MFIs and the MIV implies

$$
1+\hat{r}+t=1+\rho^{*}
$$

and $1+\rho=1+\hat{\rho}$, respectively. Together with (9), it follows that

$$
1+\rho^{*}=\frac{1+\rho+\frac{(1-q) \gamma}{l}}{q}+t
$$

That is, the expected revenue of an MFI in a good market (the left-hand side of (11)) equals the expected total cost per loan in a good market, i.e., the sum of interest, state verification, and transaction costs (the right-hand side of (11)).

\section{Choice of contract}

For public repayment, (5) and (11) together with the definition of $\Delta$ in (2) yield $1+r^{*}=\Delta$. Condition (1) implies that a successful borrower in a good market is in fact able to repay two loans. Substituting for $1+r^{*}$ into the ICC (3) and the PC (4) yields

$$
\frac{h}{\Delta} \geq 2-p+\frac{(1-p)^{2}}{p} \frac{C}{\Delta} \geq \frac{2-p}{p}
$$

For private repayment, from (2), (8), and (11), the interest rate is $1+r^{*}=(2-p) \Delta$. Condition (1) implies ability to repay. The ICC (6) and the PC (7) become

$$
\frac{h}{\Delta} \geq 2-p+\frac{1-p}{p} \frac{C}{\Delta} \geq \frac{2-p}{p} .
$$

Borrowers get higher expected utility from a contract with public repayment than from a private repayment loan. This is because the non-pecuniary penalty $C$ inflicted on unsuccessful borrowers in good markets is the only deadweight loss in the contracting problem, and the probability of exerting the penalty is lower with public repayment (viz., $(1-p)^{2}$ ) than with private repayment (viz., $1-p)^{2}$ However, the ICC is weaker with private than with public repayment (see the second inequalities in (12) and (13)), as a lower penalty is sufficient to enforce the repayment of a single loan, as compared to two loans. So we have:

Proposition 1: Let (1) hold. If (12) holds, then the equilibrium contract entails public repayment. If (13) holds and (12) does not, then the equilibrium contract entails private repayment. If neither (12) nor (13) is valid, a solution to the contracting problem does not exist.

\footnotetext{
${ }^{2}$ As shown by RS, the deadweight losses are identical if the magnitudes of the penalties under public and private repayment can be chosen freely.
} 


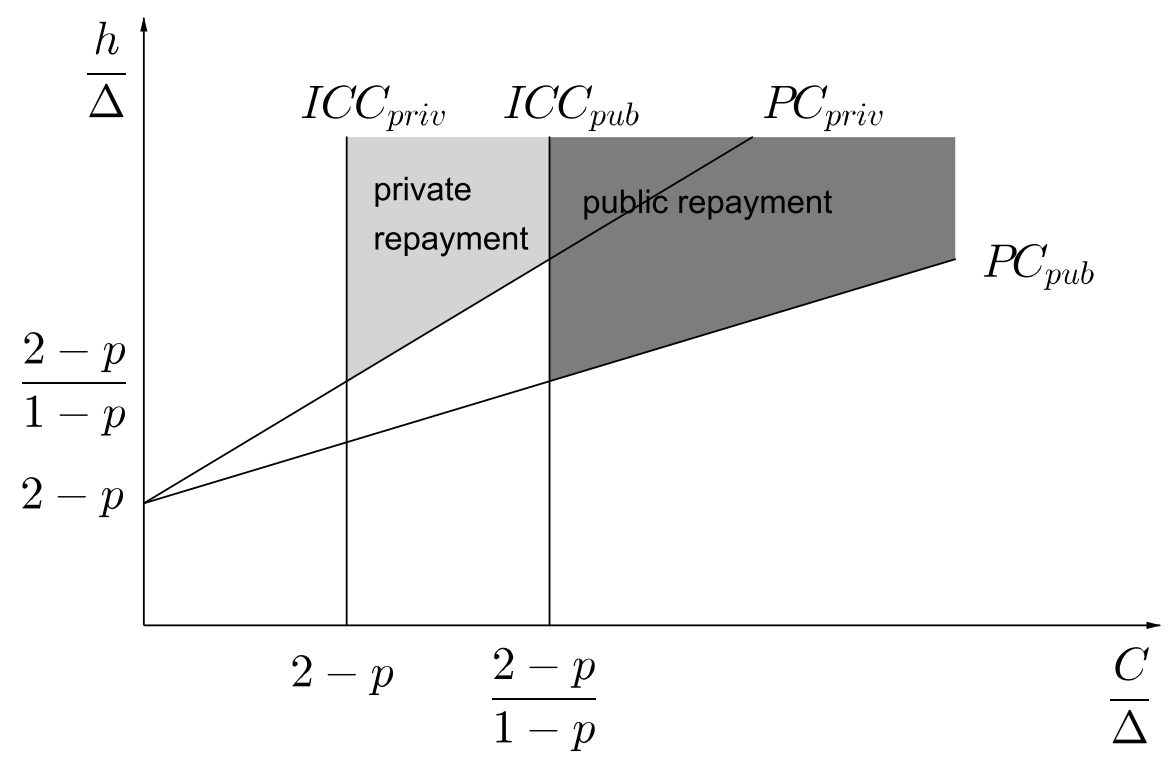

Figure 1: Equilibrium repayment type

The determination of the equilibrium repayment type is illustrated in Figure 1. The upward-sloping lines $P C_{p u b}$ and $P C_{\text {priv }}$ depict the $(C / \Delta, h / \Delta)$-combinations such that the PCs for public and private repayment (the first inequalities in (12) and (13)), respectively, hold with equality. The vertical lines $I C C_{\text {pub }}$ and $I C C_{\text {priv }}$ represent the $C / \Delta$-values such that the ICCs for public and private repayment (the second inequalities in (12) and (13)), respectively, hold with equality. For points in the cone formed by $P C_{p u b}$ and $I C C_{p u b}$ the equilibrium repayment type is public. For those points in the lightly shaded area (between $P C_{\text {priv }}$ and $I C C_{\text {priv }}$ but not in the darkly shaded cone), MFIs make loans with private repayment. For all other $(C / \Delta, h / \Delta)$-combinations, lending is not feasible.

A decrease in any cost parameter, i.e., $\rho, \gamma$, or $t$, reduces $\Delta$ (see (2)). This increases the likelihood that a solution to the contracting problem exists:

Proposition 2: Let (1) hold. Then, if the contracting problem has a solution for $\Delta=\hat{\Delta}$, (all other model parameters equal) it also has a solution for $\Delta<\hat{\Delta}$.

Proof: Suppose (1) and (12) hold for $\Delta=\hat{\Delta}$. Then, evidently, (1) and the second inequality in (12) also hold for $\Delta<\hat{\Delta}$. Validity of the first inequality in (12) implies that the derivative of the term on the left-hand side of that inequality with respect to $1 / \Delta$ is larger than the derivative of the right-hand side. So if the inequality holds for $\Delta=\hat{\Delta}$, then it also holds for $\Delta<\hat{\Delta}$. An analogous argument applies when (1) and (13) hold for $\Delta=\hat{\Delta}$. (In this case, the lending type switches to 
public repayment if the new value of $\Delta$ is such that the second inequality in (12) holds.)

Graphically, $C, h$, and $\Delta$ determine a point in Figure 1. A decrease in $\Delta$, holding everything else equal, corresponds to a rightward movement on the ray from the origin through that point. The assertion of the proposition follows from the observation that the ray does not leave the area in which a solution to the contracting problem exists. MFIs switch from private to public repayment if the decrease in $\Delta$ is sufficiently pronounced such that $C / \Delta$ grows larger than $(2-p) /(1-p)$. The upshot of the perfectly competitive version of the theoretical model is that MFIs can refinance their risky loan portfolio by borrowing from an MIV that has to meet certain return expectations if the interest, agency, and transaction costs are sufficiently low. While the focus of the empirical analysis in Section 5 is on the relation between MFIs' access to MIV capital and their market power, we will include cost variables in the regressions in order to check whether they have the predicted signs.

\section{Market power}

This section introduces market power to the model of Section 2 and attributes a social mission to the MIVs. In addition to choosing public versus private repayment, MFIs have to decide whether to exploit their market power or not. The MIV is social-minded in that it provides capital only to those MFIs which opt not to exert market power. Since the opportunity cost of MIV capital thus rises with the degree of market power, the most profitable MFIs choose not to use MIV capital at equilibrium.

\section{Model}

MFIs now have bargaining power in the determination of the terms of loans to micro-borrowers (details are specified below). They have a positive amount of equity, which is less than $l$, however. So they are unable to make loans to all potential borrowers in their local market without leveraging their equity. MIV capital is the only source of external finance. The MIV is not purely interested in financial returns but also concerned with the way MFIs act in their local market. In particular, we assume that the MIV provides finance only to MFIs that do not exploit their bargaining power. MFIs thus face the choice between two business models, commercial or social. A commercial MFI exploits its bargaining power in the market for microcredit, but cannot leverage its equity by borrowing from the social-minded MIV. A social MFI, by contrast, borrows $l$ from an MIV and makes loans to all borrowers in its market, at terms which maximize borrower expected utility subject its zero profit constraint. Its behavior in its local microcredit market is exactly as described 
in Section 3. The expected profit on its loan portfolio is zero. If a social MFI is unable to break even at the contractual repayment $\Delta$, then it remains inactive in the microfinance market. ${ }^{3}$ Both a social and an inactive MFI can invest their equity in the financial market, thereby generating final wealth $1+\rho$ per unit of equity invested. ${ }^{4}$ This is the per loan opportunity cost of choosing the commercial business model.

If an MFI has opted for the commercial business model, the terms of loans to the micro-borrowers are subsequently determined by Nash bargaining. The MFI's equity is sunk then. This is a crucial assumption. If the equity were not sunk and the MFI could still invest financially, then its disagreement payoff would be $1+\rho$, and it would necessarily get a payoff in excess of $1+\rho$ in the bargaining process. Irrespective of how low its bargaining power is, it would always opt for the commercial business model. So some sort of sunk cost is required in our model in order to have a genuine choice between social and commercial lending. To keep the model as simple as possible, we do not introduce a new cost category to the model of Section 2 (e.g., costs of training staff), but assume that the commercial MFI's equity is sunk. ${ }^{5}$

Let $u, \pi$, and $\beta(0 \leq \beta \leq 1)$ denote the borrowers' expected utility, the MFI's expected repayment per loan, and the MFI's bargaining power, respectively. The special cases $\beta=0$ and $\beta=1$ refer to a competitive and a monopolistic MFI, respectively. Since borrowers have no outside option and since the MFI's equity is sunk, both parties' disagreement payoffs are zero. When a borrower and an MFI negotiate over a loan with private repayment, the interest rate is chosen such that it maximizes the Nash product $u^{1-\beta} \pi^{\beta}$ subject to the borrower's ICC. When two borrowers and an MFI bargain over the interest rate on two loans with public repayment, one for each borrower, the borrowers' expected utilities are aggregated as $2 u$, and the Nash product is $(2 u)^{1-\beta}(2 \pi)^{\beta}$. Evidently, maximization of this Nash product is equivalent to maximization of $u^{1-\beta} \pi^{\beta}$. Thus, the share of the total surplus the MFI gets does not depend on whether it negotiates with a single borrower or with two borrowers. ${ }^{6}$ For either repayment type, both parties' surpluses from the bargain are nonnegative provided that the total surplus is non-negative. However, the MFI enters the negotiation

\footnotetext{
${ }^{3}$ Given zero expected profit, active social MFIs are indifferent between making loans or not. Any small reward would be sufficient to make lending strictly preferable to staying inactive.

${ }^{4}$ Alternatively, we could assume that social MFIs invest their equity in their loan portfolio and borrow only the difference to loan demand $l$ from the MIV. Although this is not equivalent, since the MIV's state verification cost per dollar lent is higher then, the results are identical. The chosen specification is much more convenient for our purposes, since social MFIs behave exactly like the competitive lenders of Section 3.

${ }^{5}$ The analysis goes through with slight modifications under the more general assumption that a positive fraction of the MFI's equity is sunk.

${ }^{6}$ If the negotiation with two borrowers were modeled as a three-person bargaining problem, the MFI would get a smaller share than with just one borrower involved. Our formulation of the bargaining problem implies that micro borrowers are unable to raise their bargaining power in this way.
} 
only if its repayment per loan $\pi$ is no less than the opportunity cost $1+\rho$. We call this condition the MFI's PC (though once it has sunk its equity, it would accept a surplus $\pi<1+\rho$ ).

To ensure that a successful borrower can repay two loans when repayment is public and one loan if repayment is private, we assume that the payoff of a successful project is sufficiently high and MFIs' bargaining power is sufficiently low, in that

$$
h>\max \left\{2 \Delta^{\prime}, C\right\},
$$

where

$$
\Delta^{\prime} \equiv \frac{t}{p(2-p)}
$$

and either

$$
h<2\left(\frac{1-p}{p}\right)^{2} C
$$

or, if this inequality is violated,

$$
\beta<\frac{2-p}{2} \frac{\frac{h}{\Delta^{\prime}}-2}{\frac{h}{\Delta^{\prime}}-(2-p)-\frac{(1-p)^{2}}{p} \frac{C}{\Delta^{\prime}}} .
$$

\section{Commercial MFIs}

The derivation of the optimal contract between a commercial MFI and its borrowers is somewhat tedious, so details are delegated to the Appendix. Figure 2 illustrates the determination of the equilibrium repayment type graphically. We first consider the cases of public and private repayment separately and then determine the equilibrium repayment type.

Consider first public repayment. A commercial MFI's expected profit per loan is

$$
\pi \equiv q\left[p(2-p)\left(1+r^{*}\right)-t\right]
$$

and a borrower's expected utility is

$$
u \equiv q\left[p h-p(2-p)\left(1+r^{*}\right)-(1-p)^{2} C\right]
$$

Using (15), total surplus in the Nash bargain is $2 c$, where $c \equiv q\left[p h-(1-p)^{2} C-p(2-p) \Delta^{\prime}\right]$. If the borrowers' ICC (3) is not binding, the interest rate is determined by the requirement that total surplus is divided such that $\pi=\beta c$. Total surplus and $1+r^{*}$ rise when $h$ increases or $C$ decreases. The borrowers' ICC holds with equality on the upward-sloping line $I C C_{p u b}$ in Figure 2: the higher the return on investment in case of success $h$, the higher the interest rate $1+r^{*}$ and the penalty 


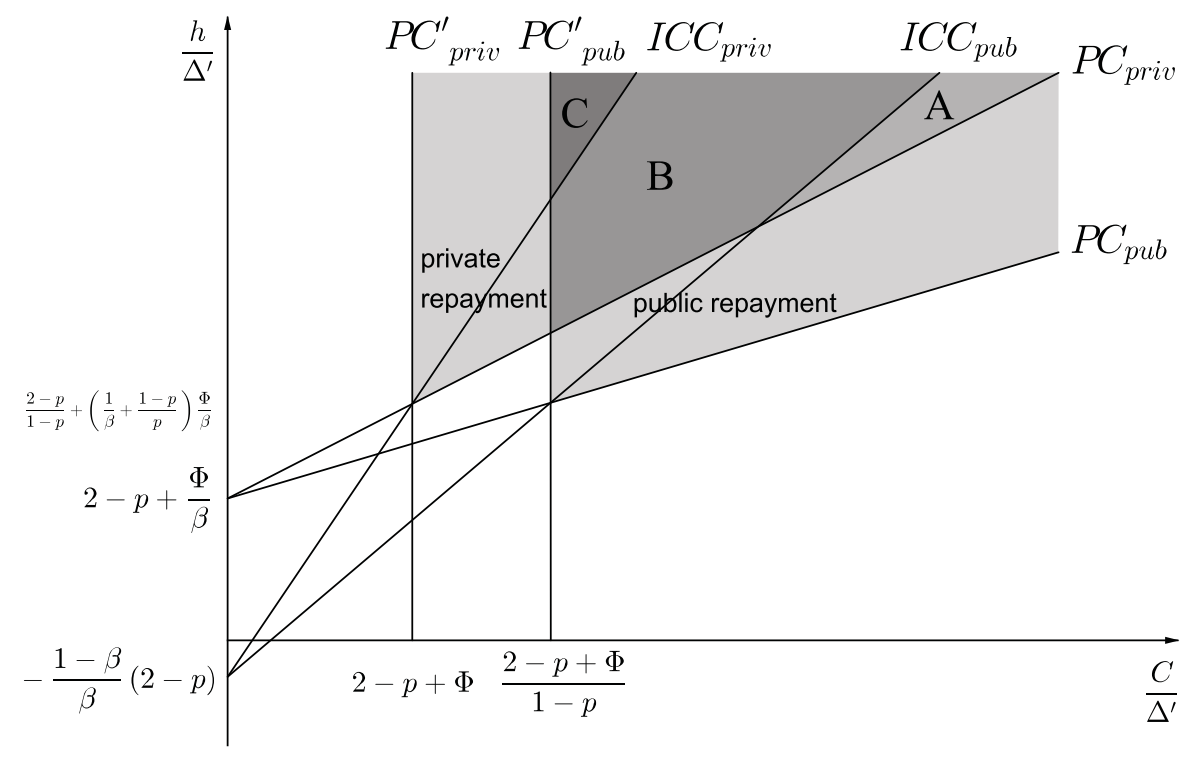

Figure 2: Equilibrium repayment type with MFI bargaining power

required to make repayment of $1+r^{*}$ incentive compatible. Below $I C C_{p u b}$, the ICC is not binding. The MFI's PC $\pi \geq 1+\rho$ holds with equality for $\left(C / \Delta^{\prime}, h / \Delta^{\prime}\right)$-combinations on the line $P C_{p u b}$ (notice that here and in what follows, other than in Section 3, the PC refers to the MFI rather than the borrowers). For future reference, we note that this line is determined by

$$
\frac{h}{\Delta^{\prime}}=\frac{\Phi}{\beta}+2-p+\frac{(1-p)^{2}}{p} \frac{C}{\Delta^{\prime}},
$$

where

$$
\Phi \equiv \frac{1+\rho}{q p \Delta^{\prime}}
$$

(see equation (A.3) in the Appendix). Validity of the MFI's PC implies that total surplus is positive. So Nash bargaining yields the unconstrained solution in the cone formed by $P C_{p u b}$ and $I C C_{p u b}$ in Figure 2 .

Above $I C C_{p u b}$ the project payoff $h$ is so large that the unconstrained optimal repayment $1+r^{*}$ violates the borrowers' ICC (3). The interest rate is then determined by the condition that the ICC holds with equality, so it depends on $C$ but not on $h$. The penalty $C$ and, hence, the interest rate are large enough such that the MFI's PC is satisfied on and to the right of the vertical line $P C_{p u b}^{\prime}$ in Figure 2. As in the case where the ICC is not binding, the borrowers "automatically" get non-negative expected utility $u$ for these parameters. So there is a bargaining solution at which the borrower's ICC is binding in the cone formed by $I C C_{p u b}$ and $P C_{p u b}^{\prime}$. 
The case of private repayment is treated analogously. A commercial MFI's profit and a borrower's expected utility are

$$
\pi \equiv q\left[p\left(1+r^{*}\right)-t\right]
$$

and

$$
u \equiv q\left\{p\left[h-\left(1+r^{*}\right)\right]-(1-p) C\right\}
$$

respectively. As in the perfectly competitive model, there is an efficiency loss relative to public repayment, since the probability of exerting the penalty $C$ is $1-p$ as compared to $(1-p)^{2}$. The borrower's ICC is given by (6). Despite the efficiency loss, there is scope for private repayment as the equilibrium lending type, since the smaller repayment is easier to enforce (i.e., (6) is weaker than (3)). The interest rate that maximizes the Nash product subject to $u+\pi=c$ satisfies the borrower's ICC and the MFI's PC on and above $I C C_{\text {priv }}$ and $P C_{\text {priv }}$, respectively. Validity of the PC implies non-negativity of total surplus. So Nash bargaining over a loan with individual repayment yields an interest rate such that the borrower's ICC is not binding in the cone formed by $P C_{\text {priv }}$ and $I C C_{\text {priv }}$ in Figure 2. As in the case of public repayment, the interest rate is independent of $h$ if the ICC (6) is binding. It is large enough so that the MFI's PC is satisfied on and to the right of the vertical line $P C_{\text {priv }}^{\prime}$. So Nash bargaining yields an interest rate such that the ICC is binding in the cone formed by $I C C_{\text {priv }}$ and $P C_{\text {priv }}^{\prime}$.

A solution to the contracting problem exists for $\left(C / \Delta^{\prime}, h / \Delta^{\prime}\right)$ in the sawtooth shaped, shaded area in Figure 2. For $C$ low enough, it is not possible to enforce repayment of two loans, so only loans with private repayment are feasible. For larger $C$-values, there is a threshold $h$-value below which only public repayment loans are feasible, as the deadweight loss caused by private repayment loans is too large. In the areas labeled A, B, and C in Figure 2, both repayment types are feasible. Whether the loan entails public or private repayment then depends on which repayment type yields the higher value of the Nash product. In the area labeled A, MFIs use public repayment. This follows from the fact the ICC is not binding for either repayment type. So the the borrower and the MFI get proportions $1-\beta$ and $\beta$, respectively, of the unconstrained maximized Nash product, which is larger for public repayment due to the lower probability of exerting the penalty $C$. In the Appendix, we show that both borrowers and MFIs also unanimously prefer public over private repayment for parameters in area B, even though the ICC is binding then. Finally, in area C, where the ICC is binding for both repayment types, MFIs prefer private repayment, but borrowers' expected utility is higher with public repayment. In the Appendix, we show that the Nash product is larger with 


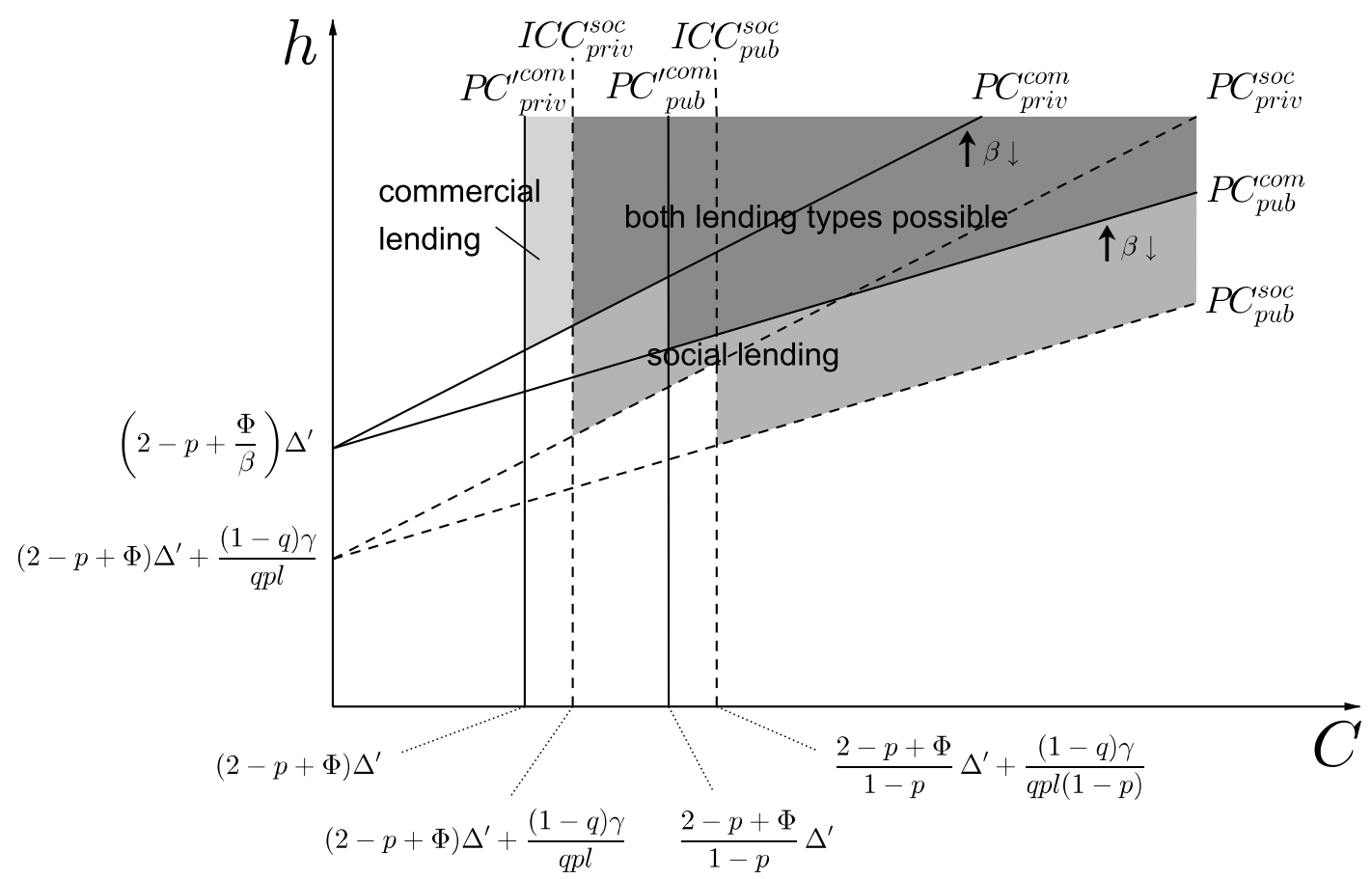

Figure 3: Equilibrium repayment types with and without MFI bargaining power

public than with private repayment exactly if MFI bargaining power is sufficiently low, in that

$$
\beta<\frac{\ln \left(1+\frac{p C}{p h-C}\right)}{\ln \left(1+\frac{p C}{p h-C}\right)+\ln \left[1+\frac{p C}{(1-p) C-(2-p) \Delta^{\prime}}\right]} .
$$

The Appendix also proves that assumptions (14)-(17) ensure that a successful borrower can repay two loans with public repayment or one loan with private repayment.

Social versus commercial MFIs

For parameters in the sawtooth-shaped shaded area in Figure 2, MFIs adopt the commercial business model. For parameters outside this area but inside the sawtooth-shaped shaded area in Figure 1 , they adopt the social business model. Figure 3 merges these two figure in a $(C, h)$-diagram. Superscripts com and soc indicate that the respective curves refer to MFIs with a commercial or social business model, respectively. The slopes of all lines in Figure 3 as well as the $h$-intercepts of $P C_{p u b}^{s o c}$ and $P C_{p r i v}^{s o c}$ are independent of $\beta$. For $\beta=1$, the $h$-intercepts of $P C_{p u b}^{c o m}$ and $P C_{p r i v}^{c o m}$ are located below the respective intercepts for the case of social lending.

As the MFIs favor commercial lending over social lending if both lending types are possible and the slopes of the PCs with commercial and social lending are equal, only commercial lending takes 
place for $\beta=1$. With falling $\beta, P C_{p u b}^{c o m}$ and $P C_{p r i v}^{c o m}$ shift upwards and an area emerges where only social lending is possible. For $\beta \rightarrow 0$ the $h$-intercept of the PCs with commercial lending diverges to infinity and only social lending takes place. For all parameters, we can derive the value of $\beta$ at which MFIs change the lending mode.

Proposition 3: Assume $C$ is between $I C C_{\text {priv }}^{s o c}$ and $P C_{\text {pub }}^{\prime c o m}$. For $h$ above $P C_{\text {priv }}^{s o c}$ the MFI chose social lending if

$$
\beta<\frac{\Phi}{\frac{h}{\Delta^{\prime}}-(2-p)-\frac{1-p}{p} \frac{C}{\Delta^{\prime}}} .
$$

Assume $C$ is on the right-hand side of $P C_{p u b}^{\prime c o m}$. If $C$ is on the left-hand side of $I C C_{p u b}^{s o c}$ and $h$ above $P C_{p r i v}^{s o c}$ or $C$ on the right-hand side of $I C C_{p u b}^{s o c}$ and $h$ above $P C_{p u b}^{s o c}$, than the MFI chose social lending if

$$
\beta<\frac{\Phi}{\frac{h}{\Delta^{\prime}}-(2-p)-\frac{(1-p)^{2}}{p} \frac{C}{\Delta^{\prime}}} .
$$

If $\beta$ is greater, the MFI chooses commercial lending.

Proof: For $\beta$ equal to the term on the right-hand side of the first inequality, the PC for commercial lending and public repayment holds with equality. For $\beta$ equal to the term on the right-hand side of the second inequality, the PC for commercial lending and private repayment holds with equality. $\|$

The smaller $\gamma$, the lower the $h$-intercept of the PCs for social lending. Hence, if MIVs can solve the state verification problem at sufficiently low cost, then when lending commercially becomes unprofitable, the preferred alternative is not to shut down the MFI altogether but to raise money from the MIV and lend at the competitive interest rate. A similar argument applies when commercial lending with private repayment becomes unprofitable.

If there is a cross section of microfinance markets, each structured as described above, one will observe relatively small commercial MFIs (with sufficiently high $\beta$ ), setting high interest rates and generating sizeable profits, in one subset of the markets and socially oriented MFIs with higher outreach, lending at competitive terms, in the other markets. This does not mean that the MIVs pick the "wrong" MFIs or are inefficient as delegated monitors, but reflects their insistence that the MFIs they refinance do not exert their market power in the market for microfinance.

\section{Empirical evidence}

This section presents empirical evidence on how MFIs obtain finance and make loans. We formulate several hypotheses derived from, or motivated by, the theoretical model of the preceding sections 
and test them empirically using a large data set on MFIs. The focus in on the relation between MFI market power and the use of MIV finance. Our proxy for MFI market power is their net interest margin defined as the ratio of net interest income, i.e., interest and fee income minus financial expenses and loan losses, to the volume of outstanding loans. This measure corresponds roughly to the interest rate premium (the difference between the interest rate on microcredit minus the rate at which MFIs obtain funds), proposed by Yunus (2007) to classify MFIs according to the degree of profit maximization. We do not subtract operating expenses from interest and fee income, but include the ratio of total expenses to total assets as a separate regressor.

\section{Hypotheses}

The central result of the theoretical model is that MFIs with sufficiently high bargaining power in the market for microcredit do not tap the market for MIV capital (Proposition 3). With the net interest margin as our proxy for market power, we thus conjecture:

Hypothesis A1: The use of MIV funds is negatively related to the net interest margin.

Generally, it is easier for MFIs with a high net interest margin to repay their debt. If, nonetheless, the data confirm the inverse relation between the net interest margin and MIV access in A1, this can be interpreted as strong evidence for the relevance of the mechanism at work in our model.

Opting for the social business model enables MFIs to leverage their capital in our model, so social MFIs have a larger loan portfolio. Making loans to MFIs causes state verification costs, however, in our model, which can be regarded as an example of the different types of agency costs arising in the MIV-MFI relationship. So social MFIs are predicted to have a higher cost of capital than commercial MFIs:

Hypothesis A2: The use of MIV funds is positively related to the size of the loan portfolio.

Hypothesis A3: The use of MIV funds is positively related to the costs of an MFI.

Our MFI data also includes information on individual versus joint liability. We use this information to perform a further robustness check of our model. As remarked in Section 3, it does not matter whether there is individual or joint liability for loans with public repayment, since borrowers insure themselves via side contracting anyway. By contrast, there is no joint liability for loans with individual repayment. So if a fraction of the public repayment loans are designated as joint liability loans, then parameter changes which make public repayment more likely increase the likelihood of joint liability.

Hypothesis R1: For commercial MFIs, bargaining power is negatively related to the share of joint liability. 
This is because, as explained in Section 4, the set of parameter values which lead to private repayment grows when $\beta$ rises.

Hypothesis R2: MFI costs are negatively related to the share of joint liability.

This is the assertion of Proposition 2 of the perfectly competitive model. The same conclusion also follows from the model with market power.

Studies of gender effects in microfinance point out that women are particularly vulnerable to the social penalties used by MFIs to enforce microloans (see, e.g., Rahman, 1999). So a larger share of female borrowers can be interpreted as a higher value of the non-pecuniary penalty $C$ in our model. Since public repayment is the only way to enforce repayment for sufficiently high values of $C$ in our model, we have:

Hypothesis R3: The share of female borrowers is positively related to the share of joint liability.

\section{Data and methodology}

Data were obtained from the Microfinance Information Exchange (MIX). The dataset covers 5,299 observations (1,757 MFIs) from 110 countries over the years 2007-2010. 1,330 observations are characterized by funding from MIVs.

First, we check whether the descriptive statistics of the MFIs in our data sample are in line with the characteristics implied by the theoretical model. Then a regression analysis is performed. Due to the short and unbalanced nature of the panel, we estimate pooled logit regressions using MFI-clustered standard errors to examine the determinants of the access to MIV debt. The dependent variable in our regressions is a dummy variable indicating whether an MFI has access to debt financing from MIVs. In our baseline model, the set of regressors is confined to variables derived from the theoretical model. The net interest margin serves as a proxy for $\beta$. The gross loan portfolio serves as a proxy for $l$. To measure costs, we use total expenses.

In further regressions, we add macroeconomic, MFI-specific, and country-specific variables. The macroeconomic control variables are the level and growth rate of gross domestic product (GDP). The MFI-specific variables are MFI age, three dummy variables indicating whether the MFI receives donations, takes deposits, and is subject to regulation, a dummy variable that indicates whether an MFI operates non-profit or not, the fraction of female borrowers (as indicators of the MFI's social performance), the average outstanding balance, and MFI type (legal status). Finally, we control for the MFI's region. The variables are defined in Table 1.

Results

MFIs reporting to MIX indicate whether they operate for-profit or non-profit. The differences 
Table 1: Definition of variables.

\begin{tabular}{|c|c|}
\hline Variable & Description \\
\hline $\begin{array}{l}\text { Yield on gross portfolio } \\
\text { (nominal) }\end{array}$ & $\begin{array}{l}\text { Cash flows of all interest, fees and commission payments received in the period under } \\
\text { consideration in relation to the average gross loan portfolio of the same period. Source: MIX } \\
\text { Market. }\end{array}$ \\
\hline Net interest margin & $\begin{array}{l}\text { Yield on gross portfolio minus financial expense and write-offs adjusted for value of loans } \\
\text { recovered divided by average gross loan portfolio. Derived from MIX Market data. }\end{array}$ \\
\hline $\begin{array}{l}\text { Gross loan portfolio } \\
\text { (GLP) }\end{array}$ & $\begin{array}{l}\text { Value of all principal loan amounts due at the end of the reporting period. Incorporates } \\
\text { current, delinquent and renegotiated loans, but excludes loans that have been written off. Unit: } \\
\text { USD. Source: MIX. }\end{array}$ \\
\hline $\begin{array}{l}\text { Number of active } \\
\text { borrowers }\end{array}$ & Number of active borrowers. Source: MIX. \\
\hline Total expense/assets & Total expense divided by average assets. Source: MIX. \\
\hline Age in years & Time (in years) the MFI has existed. Derived from MIX Market data. \\
\hline Capital/asset ratio & Total equity divided by total assets. Source: MIX. \\
\hline Debt to equity ratio & Total liabilities divided by total equity. Source: MIX. \\
\hline $\begin{array}{l}\text { Percent of female } \\
\text { borrowers }\end{array}$ & Share of microcredit clients that are female. Source: MIX. \\
\hline $\begin{array}{l}\text { Average outstanding } \\
\text { balance }\end{array}$ & $\begin{array}{l}\text { Average gross loan portfolio divided by the number loans outstanding of the institution. } \\
\text { Source: MIX. Unit: USD. }\end{array}$ \\
\hline Profit status & $\begin{array}{l}\text { Indicates if an MFI operate for profit or not (non-profit). Time-invariant dummy variables. } \\
\text { Source: MIX. }\end{array}$ \\
\hline Percent of group lending & $\begin{array}{l}\text { Share of active microborrowers that receive group loans, either via solidarity lending or village } \\
\text { banking. Derived from MIX Market data. }\end{array}$ \\
\hline Return on assets & Net operating income less taxes divided by average assets. Source: MIX. \\
\hline Loan loss rate & $\begin{array}{l}\text { Value of lonas written off minus value of loans recovered divided by average gross loan } \\
\text { portfolio. Source: MIX. }\end{array}$ \\
\hline Portfolio at risk 30 days & $\begin{array}{l}\text { Measures the unpaid principal of loans on which installments have been } 30 \text { days past due and } \\
\text { is based on the total outstanding credit balance. Source: MIX. }\end{array}$ \\
\hline $\begin{array}{l}\text { Financial } \\
\text { expense/assets }\end{array}$ & Operating expense divided by average assets. \\
\hline $\begin{array}{l}\text { Operating } \\
\text { expense/assets }\end{array}$ & Operating expense divided by average assets. Source: MIX. \\
\hline GDP & $\begin{array}{l}\text { Derived from the World Bank data platform. USD value of gross domestic product of the } \\
\text { country, in which the MFI mainly operates. Unit: (current) USD. }\end{array}$ \\
\hline GDPgrowth & Derived from the World Bank data platform. Growth rate of the GDP (annual percent). \\
\hline Donations & $\begin{array}{l}\text { Dummy variable indicating if an MFI received donations. Missing values are treated as zero. } \\
\text { Derived from MIX Market data. }\end{array}$ \\
\hline Deposits & $\begin{array}{l}\text { Dummy variable indicating whether an MFI takes deposits. Missing values are treated as zero. } \\
\text { Derived from MIX Market data. }\end{array}$ \\
\hline Regulated & $\begin{array}{l}\text { Describes whether an MFI is subject to the supervision of a regulatory authority. Missing } \\
\text { values are treated as zero. Time-invariant dummy variable. Source: MIX. }\end{array}$ \\
\hline Type & $\begin{array}{l}\text { Legal status of the MFI. The data set includes banks, credit unions, nonbank financial } \\
\text { institutions, nongovernmental organizations, and other types of MFIs. The category 'Other' } \\
\text { also contains rural banks and unknown organizational types. Time-invariant dummy variables. } \\
\text { Source: MIX. }\end{array}$ \\
\hline Region & $\begin{array}{l}\text { The geographical regions are Latin America and the Caribbean, the Middle East and North } \\
\text { Africa, Africa, South Asia, Eastern Europe and Central Asia, and East Asia and the Pacific } \\
\text { Area. Dummy variables. Source: MIX. }\end{array}$ \\
\hline
\end{tabular}

Note: Unless indicated otherwise the variables are relative measures.

between MFIs with and without access to funds from MIVs are shown in Table 2. Observations with MIV funding appear to be more mature in terms of the age of the institution as well as larger regarding number of active borrowers and gross loan portfolio. Consistent with our theoretical 
model, observations without access to MIV debt have a greater average value for the net interest margin.

Table 2: Number of observations and means for selected metric variables by access to MIV funding.

\begin{tabular}{|c|c|c|c|c|c|c|c|}
\hline & \multicolumn{2}{|c|}{ total } & \multicolumn{2}{|c|}{ MFIs with access } & \multicolumn{2}{|c|}{ MFIs without access } & \multirow[b]{2}{*}{ mean differences } \\
\hline & $\mathrm{N}$ & mean & $\mathrm{N}$ & mean & $\mathrm{N}$ & mean & \\
\hline Net interest margin & 3993 & 0.251 & 1302 & 0.232 & 2691 & 0.260 & $-0.028 * * *$ \\
\hline Gross loan portfolio & 5167 & 42.185 & 1329 & 53.733 & 3838 & 38.186 & $15.546^{* *}$ \\
\hline Number of active borrowers & 4801 & 65.908 & 1320 & 69.012 & 3481 & 64.730 & 4.282 \\
\hline Total expense/assets & 4260 & 0.261 & 1308 & 0.249 & 2952 & 0.266 & $-0.017^{* * *}$ \\
\hline Age in years & 5154 & 12.885 & 1328 & 13.768 & 3826 & 12.578 & $1.190 * * *$ \\
\hline Capital/asset ratio & 5030 & 0.315 & 1321 & 0.260 & 3709 & 0.335 & $-0.075^{* * *}$ \\
\hline Debt to equity ratio & 4814 & 4.798 & 1319 & 5.015 & 3495 & 4.716 & 0.299 \\
\hline Percent of female borrowers & 3886 & 0.636 & 1216 & 0.650 & 2670 & 0.629 & $0.020 * *$ \\
\hline Percent of group lending & 3841 & 0.436 & 1194 & 0.435 & 2647 & 0.437 & -0.002 \\
\hline Return on assets & 4257 & 0.004 & 1308 & 0.021 & 2949 & -0.003 & $0.025^{* * *}$ \\
\hline Yield on gross portfolio (nominal) & 4121 & 0.340 & 1307 & 0.329 & 2814 & 0.345 & $-0.017^{* * *}$ \\
\hline Loan loss rate & 4183 & 0.016 & 1308 & 0.016 & 2875 & 0.017 & -0.001 \\
\hline Portfolio at risk 30 days & 4155 & 0.072 & 1307 & 0.054 & 2848 & 0.080 & $-0.027^{* * *}$ \\
\hline Financial expense/assets & 4239 & 0.054 & 1307 & 0.063 & 2932 & 0.049 & $0.014^{* * *}$ \\
\hline Operating expense/assets & 4253 & 0.190 & 1308 & 0.167 & 2945 & 0.200 & $-0.032^{* * *}$ \\
\hline Observations & 5299 & & 1330 & & 3969 & & \\
\hline
\end{tabular}

Notes: ${ }^{a}$ In thousands.

${ }^{b}$ In million USD.

To investigate the characteristics of non-profit and for-profit MFIs in our data sample, Table 3 presents descriptive statistics for selected variables by both types of MFIs. While non-profit MFIs seem to be more mature regarding their age, for-profit MFIs appear to be larger in terms of number of active borrowers and gross loan portfolio. Again, in line with the results of the theoretical model,

Table 3 reports a higher value of net interest margin for for-profit MFIs.

Table 3: Number of observations and means for selected metric variables by profit status.

\begin{tabular}{|c|c|c|c|c|c|c|c|}
\hline & \multicolumn{2}{|c|}{ total } & \multicolumn{2}{|c|}{ Non-profit MFIs } & \multicolumn{2}{|c|}{ For-profit MFIs } & \multirow[b]{2}{*}{ mean differences } \\
\hline & $\mathrm{N}$ & mean & $\mathrm{N}$ & mean & $\mathrm{N}$ & mean & \\
\hline Net interest margin & 3993 & 0.251 & 2431 & 0.238 & 1562 & 0.271 & $-0.033^{* * *}$ \\
\hline Gross loan portfolio & 5167 & 42.185 & 3044 & 20.664 & 2123 & 73.042 & $-52.377^{* * *}$ \\
\hline Number of active borrowers & 4801 & 65.908 & 2841 & 53.666 & 1960 & 83.651 & $-29.985^{* *}$ \\
\hline Total expense/assets & 4260 & 0.261 & 2577 & 0.257 & 1683 & 0.267 & -0.011 \\
\hline Age in years & 5154 & 12.885 & 3022 & 14.108 & 2132 & 11.151 & $2.957^{* * *}$ \\
\hline Capital/asset ratio & 5030 & 0.315 & 2989 & 0.325 & 2041 & 0.3 & $0.025^{* * *}$ \\
\hline Debt to equity ratio & 4814 & 4.798 & 2885 & 5.056 & 1929 & 4.412 & 0.643 \\
\hline Percent of female borrowers & 3886 & 0.636 & 2430 & 0.657 & 1456 & 0.6 & $0.057^{* * *}$ \\
\hline Percent of group lending & 3841 & 0.436 & 2299 & 0.46 & 1542 & 0.401 & $0.058^{* * *}$ \\
\hline Return on assets & 4257 & 0.004 & 2573 & 0.002 & 1684 & 0.008 & -0.006 \\
\hline Yield on gross portfolio (nominal) & 4121 & 0.340 & 2495 & 0.321 & 1626 & 0.37 & $-0.049^{* * *}$ \\
\hline Loan loss rate & 4183 & 0.016 & 2541 & 0.015 & 1642 & 0.018 & $-0.003^{*}$ \\
\hline Portfolio at risk 30 days & 4155 & 0.072 & 2483 & 0.072 & 1672 & 0.072 & 0.000 \\
\hline Financial expense/assets & 4239 & 0.054 & 2559 & 0.051 & 1680 & 0.057 & $-0.005^{* * *}$ \\
\hline Operating expense/assets & 4253 & 0.190 & 2572 & 0.188 & 1681 & 0.192 & -0.003 \\
\hline Observations & 5299 & & 3103 & & 2196 & & \\
\hline
\end{tabular}

Notes: ${ }^{a}$ In thousands.

${ }^{b}$ In million USD. 


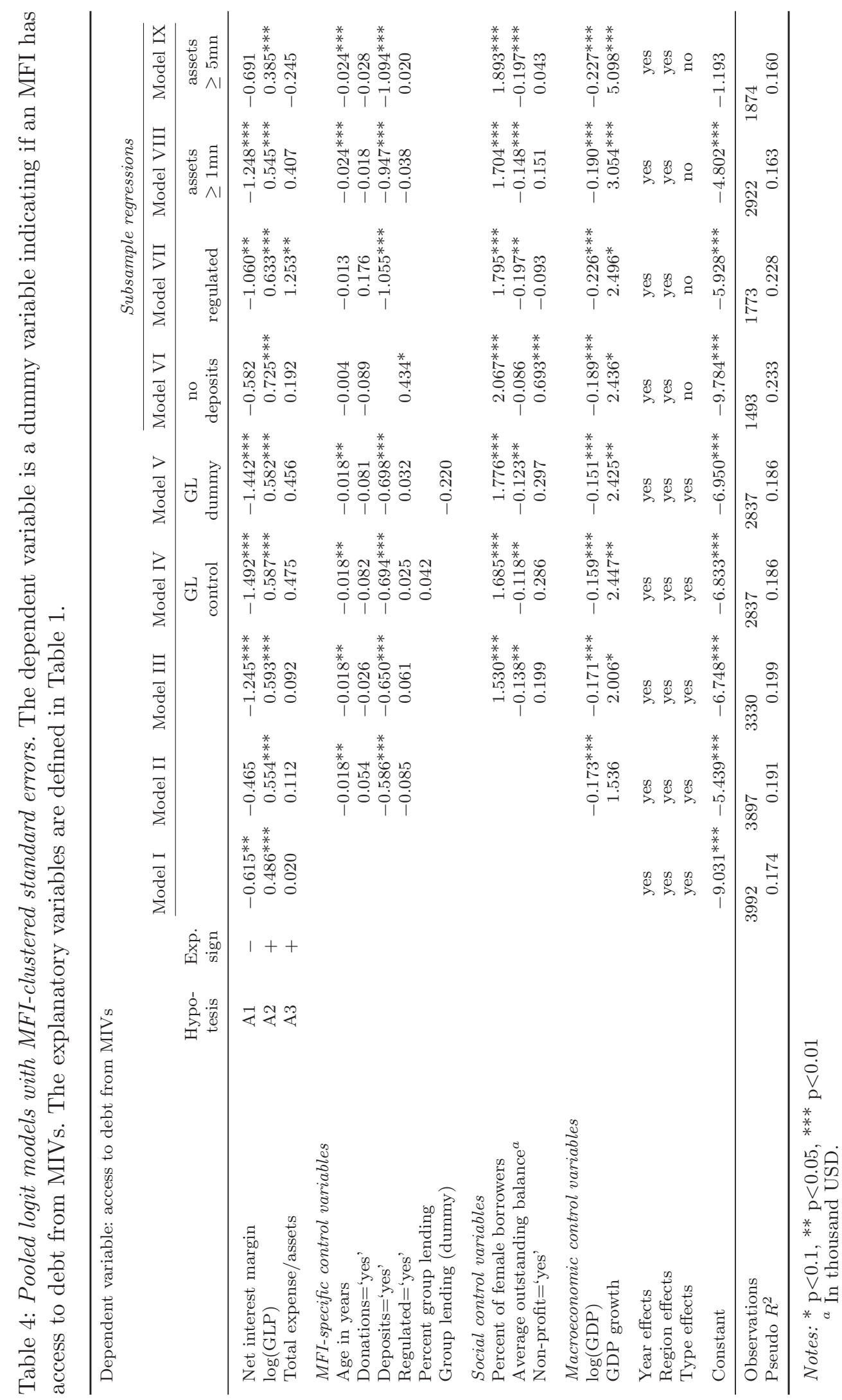


Table 4 presents the results of the logit regressions. Model I includes variables derived from the theoretical model related to the hypotheses A1-A3 and region as well as type dummy variables. Model II adds additional MFI-specific as well as macroeconomic control variables. Model III includes a set of variables which can be seen as proxies for the social performance of an MFI. Model specification IV corresponds to model III, but additionally considers the fraction of loans granted via group lending. Model V alternatively employs a group loan dummy instead of the fraction of group loans. This indicator variable takes the value 1 if an MFI has more than 99 percent group loans, and 0 otherwise. Model specifications VI-IX present various subsample estimations.

The gross loan portfolio has a significant positive relationship with access to MIV debt. This is consistent with the theoretical model's predictions that an increase in the number of borrowers per market $l$ is conducive to the existence of a solution to the contracting problems. Furthermore, the probability of access to MIV debt rises with decreasing costs in terms of total expenses. However, this effect is not significant. Moreover, specifications I, III-V, VII, and VII of the empirical model yield a negative and significant relationship between the net interest margin and access to debt from MIVs. Because MFIs with sufficiently low values for $\beta$ have access to MIV funds according to the theoretical model, the negative sign of the net interest margin is in line with the theoretical results. The average marginal effect (AME) corresponding to the significant coefficients of the net interest margins in Table 4 ranges from -0.11 (model specification I) to -0.27 (model specification IV). For example, the AME of the net interest margin in model specification III comprises -0.22 . Hence, an increase of the net interest margin of one percentage point ${ }^{7}$ results in a decrease of the likelihood to use MIV funding of approximately 0.22 percentage points.

Regarding the control variables, another significant and plausible result is the negative coefficient of the deposits dummy. Either MFIs that collect deposits are not demanding debt from MIVs because deposits serve as a cheap type of funding or MIVs are not willing to invest in MFIs with other funding sources.

Next, we turn to the determinants of individual versus joint liability. As information on the lending mode has been collected only for 2009, we exclude the other years from this analysis. Table 5 presents additional empirical evidence regarding the hypotheses R1-R3 with the percentage of group loans as dependent variable. Moreover, Table 6 shows the results for the respective logit regressions with a group loan dummy as dependent variable.

We employ the percent of group loans as a proxy for public repayment. According to the theoretical model, lower costs should be related with a higher share of public repayment, while there should

\footnotetext{
${ }^{7}$ As the standard deviation of the net interest margin is 0.19 in this sample, a change of one percentage point can be considered as relatively small.
} 
be a positive relationship between non-pecuniary penalties and public repayment. We are not able to measure non-pecuniary penalties, however, we expect female borrowers to suffer more from these penalties. Hence, we expect a positive relationship between the fraction of female borrowers and group loans. Furthermore, commercial MFIs should show a negative relationship between the bargaining power and public repayment according to the theoretical model.

Table 5: OLS regressions with country-clustered standard errors. The dependent variable is the percentage of group loans. The explanatory variables are defined in Table 1.

\begin{tabular}{|c|c|c|c|c|c|c|c|c|c|}
\hline \multicolumn{3}{|c|}{ Dependent variable: Percent of group lending } & \multicolumn{3}{|c|}{ Full sample } & \multirow[b]{2}{*}{$\begin{array}{l}\text { Hypo- } \\
\text { tesis }\end{array}$} & \multirow[b]{2}{*}{$\begin{array}{l}\text { Exp. } \\
\text { sign }\end{array}$} & \multicolumn{2}{|c|}{$\begin{array}{l}\text { MFIs without access } \\
\text { to funds from MIVs }\end{array}$} \\
\hline & $\begin{array}{l}\text { Hypo- } \\
\text { tesis }\end{array}$ & $\begin{array}{l}\text { Exp. } \\
\text { sign }\end{array}$ & Model I & Model II & Model III & & & Model VI & Model V \\
\hline Net interest margin & & & $0.252^{* * *}$ & 0.127 & 0.121 & $\mathrm{R} 1$ & - & 0.127 & -0.001 \\
\hline Total expense/assets & $\mathrm{R} 2$ & - & 0.118 & 0.070 & 0.071 & $\mathrm{R} 2$ & - & 0.117 & 0.112 \\
\hline Percent of female borrowers & $\mathrm{R} 3$ & + & $0.714^{* * *}$ & $0.672^{* * *}$ & $0.677^{* * *}$ & R3 & + & $0.635^{* * *}$ & $0.608^{* * *}$ \\
\hline $\begin{array}{l}\text { MFI-specific control variables } \\
\log (\mathrm{GLP}) \\
\text { Age in years } \\
\text { Donations='yes' } \\
\text { Deposits='yes' } \\
\text { Regulated='yes' } \\
\text { Access='yes' }\end{array}$ & & & & $\begin{array}{r}-0.007 \\
-0.000 \\
0.031 \\
-0.020 \\
-0.003\end{array}$ & $\begin{array}{r}-0.005 \\
-0.000 \\
0.031 \\
-0.023 \\
-0.003 \\
-0.020\end{array}$ & & & & $\begin{array}{r}-0.001 \\
0.000 \\
0.052 \\
-0.024 \\
0.023\end{array}$ \\
\hline $\begin{array}{l}\text { Social control variables } \\
\text { Average outstanding balance }{ }^{a} \\
\text { Non-profit='yes' }\end{array}$ & & & & $\begin{array}{l}-0.049^{* * *} \\
0.047\end{array}$ & $\begin{array}{l}-0.050^{* * *} \\
0.048\end{array}$ & & & & $\begin{array}{l}-0.046^{* * *} \\
0.062\end{array}$ \\
\hline $\begin{array}{l}\text { Macroeconomic control variabl } \\
\log (\mathrm{GDP}) \\
\text { GDP growth }\end{array}$ & & & & $\begin{array}{l}0.007 \\
0.808\end{array}$ & $\begin{array}{l}0.007 \\
0.813\end{array}$ & & & & $\begin{array}{l}0.005 \\
1.051^{*}\end{array}$ \\
\hline $\begin{array}{l}\text { Region effects } \\
\text { Type effects }\end{array}$ & & & $\begin{array}{l}\text { yes } \\
\text { yes }\end{array}$ & $\begin{array}{l}\text { yes } \\
\text { yes }\end{array}$ & $\begin{array}{l}\text { yes } \\
\text { yes }\end{array}$ & & & $\begin{array}{l}\text { yes } \\
\text { yes }\end{array}$ & $\begin{array}{l}\text { yes } \\
\text { yes }\end{array}$ \\
\hline Constant & & & -0.020 & 0.028 & 0.016 & & & 0.118 & 0.039 \\
\hline $\begin{array}{l}\text { Observations } \\
\text { Adjusted } R^{2}\end{array}$ & & & $\begin{array}{l}830 \\
0.400\end{array}$ & $\begin{array}{l}815 \\
0.426\end{array}$ & $\begin{array}{l}815 \\
0.426\end{array}$ & & & $\begin{array}{l}524 \\
0.381\end{array}$ & $\begin{array}{l}511 \\
0.411\end{array}$ \\
\hline
\end{tabular}

Notes: $* \mathrm{p}<0.1, * * \mathrm{p}<0.05, * * * \mathrm{p}<0.01$

${ }^{a}$ In thousand USD.

While we are not able to confirm or reject our hypotheses on costs and net interest margin, our results show the expected significant positive relationship between fraction of female borrowers and public repayment across all model specifications. 
Table 6: Logit regressions with country-clustered standard errors. The dependent variable is a dummy variable indicating if group loans are the predominant lending methodology. The explanatory variables are defined in Table 1.

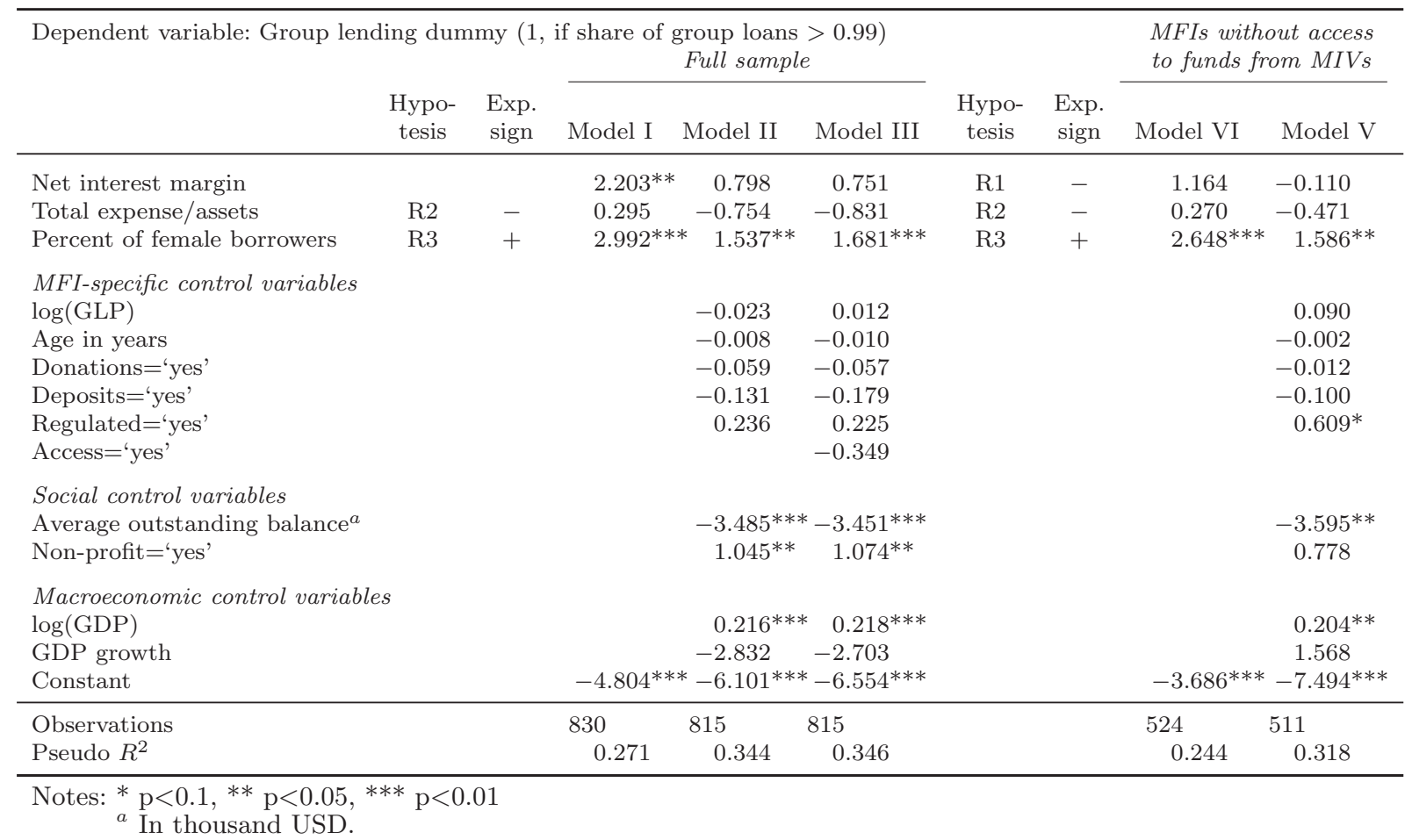

\section{Conclusion}

Refinancing microfinance, and in a way that benefits poor borrowers, is set to remain a big challenge in economic development. MFIs will have to meet the return expectations of their suppliers of capital, be they purely return-oriented or social-minded. This paper presents a model of the microfinance financing chain, in which financial claims originating in markets where enforcement relies on non-pecuniary penalties are converted into legally enforceable claims by MIVs, which act as delegated monitors of the MFIs for investors. The process of channeling funds from investors to microborrowers succeeds if the capital, agency, and transaction costs are sufficiently low. If MIVs fund MFIs with relatively low profitability, this does not necessary reflect an inefficiency. We show that this is possibly a reflection of the social mission they pursue, which makes them unattractive as financiers for MFIs with high degrees of market power. The empirical analysis supports this hypothesis: the net interest margin is negatively correlated with the use of MIV finance. 


\section{References}

Dam, Kaniska, and Prabal R. Chowdhury (2014), "Incentives and competition in microfinance", CIDE Working Paper 579, Centro de Investigación y Docencia Económicas, Mexico City.

De Corte, Jean-Marie, Marc Labie, Ludovic Urghege, and Jean-Claude Vansinck (2012), "Microfinance Investment Vehicles and Social Performance: Moving forward with the MACBETH Approach", CEB Working Paper 12/025, Solvay Brussels School of Economics and Management, Centre Emile Bernheim.

De Quidt, Jonathan, Thiemo R. Fetzer, and Maitreesh Ghatak (2013), "Market Structure and Borrower Welfare in Microfinance", CAGE Online Working Paper Series 123, University of Warwick.

Diamond, Douglas W. (1984), "Financial Intermediation and Delegated Monitoring", Review of Economic Studies 51, 393-414.

Gale, Douglas, and Martin Hellwig (1985), "Incentive-Compatible Debt Contracts: The OnePeriod Problem", Review of Economic Studies 52, 647-63.

Giné, Xavier, and Dean S. Karlan (2014), "Group versus individual liability: Short and long term evidence from Philippine microcredit lending groups", Journal of Development Economics $107,65-83$.

Goodman, Patrick (2006), "Microfinance Investment Funds: Objectives, Players, Potential", in: Ingrid Matthäus-Meier and J. D. von Pischke, Microfinance Investment Funds: Leveraging Private Capital for Economic Growth and Poverty Reduction, Chapter 2, Berlin: Springer.

Hoff, Karla, and Joseph E. Stiglitz (1997), "Moneylenders and bankers: price-increasing subsidies in a monopolistically competitive market", Journal of Development Economics 52, 429-62.

Mersland, Roy, Randøy, Trond, and Strøm, Reidar Øystein (2013), "The impact of international influence on microbanks' performance: A global survey", International Business Review 20, $163-76$.

Mersland, Roy, and Urgeghe, Ludovic (2013), "International Debt Financing and Performance of Microfinance Institutions", Strat. Change 22, 17-29.

MicroRate (2013), The State of Microfinance Investment 2013, Survey and Analysis of MIVs 8th Edition, MicroRate, Arlington, VA. 
Rahman, Aminur (1999), "Micro-credit Initiatives for Equitable and Sustainable Development:

Who Pays?", World Development 27, 67-82.

Rai, Ashok S., and Tomas Sjöström (2004), "Is Grameen Lending Efficient? Repayment Incentives and Insurance in Village Economies", Review of Economic Studies 71, 217-34.

Rai, Ashok S., and Tomas Sjöström (2013), "Redesigning Microcredit", in Nir Vulkan, Alvin E. Roth, and Zvika Neeman (eds.), The Handbook of Market Design, Chapter 9, Oxford: Oxford University Press.

Williamson, Stephen D. (1986), "Costly monitoring, financial intermediation, and equilibrium credit rationing", Journal of Monetary Economics 18, 159-79.

Yunus, Muhammad (2007), Creating a World Without Poverty: Social Business and the Future of Capitalism, New York: Public Affairs.

\section{Appendix}

This appendix presents details of the derivation of the optimum contract with MFI bargaining power omitted in the main text.

\section{Public repayment}

The total surplus is non-negative (i.e., $c \geq 0$ ) if

$$
\frac{h}{\Delta^{\prime}} \geq 2-p+\frac{(1-p)^{2}}{p} \frac{C}{\Delta^{\prime}}
$$

Suppose the ICC (3) is not binding, so that $\pi$ maximizes $(c-\pi)^{1-\beta} \pi^{\beta}$. The necessary and sufficient optimality condition yields $\pi=\beta c$. The interest rate is obtained by substituting the definitions of $\pi$ and $c$ :

$$
1+r^{*}=\beta \frac{p h-(1-p)^{2} C}{p(2-p)}+(1-\beta) \Delta^{\prime}
$$

The borrower's ICC is in fact not binding if

$$
\frac{h}{\Delta^{\prime}} \leq-\frac{1-\beta}{\beta}(2-p)+(1-p)\left(\frac{1}{\beta}+\frac{1-p}{p}\right) \frac{C}{\Delta^{\prime}}
$$

$I C C_{p u b}$ in Figure 2 represents the $\left(C / \Delta^{\prime}, h / \Delta^{\prime}\right)$-combinations that satisfy (A.2) with equality. The MFI's PC $\pi \geq 1+\rho$ is

$$
\frac{h}{\Delta^{\prime}} \geq 2-p+\frac{\Phi}{\beta}+\frac{(1-p)^{2}}{p} \frac{C}{\Delta^{\prime}}
$$


where $\Phi$ is defined in the main text. $P C_{p u b}$ in Figure 2 represents (A.3) with equality (see (18)). Evidently, (A.3) implies that the total surplus is positive.

If (3) is binding, the interest rate is given by

$$
1+r^{*}=\frac{1-p}{2-p} C
$$

The MFI's PC is

$$
\frac{C}{\Delta^{\prime}} \geq \frac{2-p+\Phi}{1-p} .
$$

$P C_{p u b}^{\prime}$ represents (A.4) with equality. The borrower's PC $u \geq 0$ can be written as

$$
\frac{h}{\Delta^{\prime}} \geq \frac{1-p}{p} \frac{C}{\Delta^{\prime}}
$$

This inequality is valid, whenever the MFI's PC holds. To see this, notice that the borrower's PC holds on and above the upward-sloping line given by (A.5) with equality. This line (not depicted in Figure 2) intersects $I C C_{p u b}$ from above at $C / \Delta^{\prime}=(2-p) /(1-p)$. Hence, the line is located below $I C C_{p u b}$ for $C / \Delta^{\prime}$ which satisfy (A.4), so validity of the MFI's PC implies validity of the borrower's PC.

Private repayment

Total surplus is non-negative if

$$
\frac{h}{\Delta^{\prime}} \geq 2-p+\frac{1-p}{p} \frac{C}{\Delta^{\prime}} .
$$

As in the case of public repayment, $\pi=\beta c$ if the ICC is not binding. Substituting the expressions for $\pi$ and $c$ for the case of individual repayment, we get the interest rate on an individual liability loan:

$$
1+r^{*}=\beta\left(h-\frac{1-p}{p} C\right)+(1-\beta)(2-p) \Delta^{\prime} .
$$

The ICC is then in fact not binding if

$$
\frac{h}{\Delta^{\prime}} \leq-\frac{1-\beta}{\beta}(2-p)+\left(\frac{1}{\beta}+\frac{1-p}{p}\right) \frac{C}{\Delta^{\prime}} .
$$

$I C C_{\text {priv }}$ represents (A.6) with equality. The MFI's PC is

$$
\frac{h}{\Delta^{\prime}} \geq 2-p+\frac{\Phi}{\beta}+\frac{1-p}{p} \frac{C}{\Delta^{\prime}},
$$

which implies that total surplus is positive. $P C_{\text {priv }}$ represents (A.7) with equality. 
If the borrower's ICC is binding, the contractual repayment is $1+r^{*}=C$, and the PCs are

$$
\frac{C}{\Delta^{\prime}} \geq 2-p+\Phi
$$

for the MFI and

$$
\frac{h}{\Delta^{\prime}} \geq \frac{1}{p} \frac{C}{\Delta^{\prime}}
$$

for the borrower. $P C_{\text {priv }}^{\prime}$ represents (A.8) with equality. Validity of (A.8) implies that (A.9) also holds. This follows from the observation that (A.9) with equality determines a straight line (not depicted) in Figure 2, which intersects $I C C_{\text {priv }}$ from above at $C / \Delta^{\prime}=2-p$.

\section{Choice of contract}

Consider the area labeled B in Figure 2. MFIs expected profit $\pi$ evaluated at the interest rate for public repayment when the ICC is binding is no less than evaluated at the interest rate for private repayment when the ICC is not binding if

$$
\frac{h}{\Delta^{\prime}} \leq-\frac{1-\beta}{\beta}(2-p)+(1-p)\left(\frac{1}{\beta}+\frac{1}{p}\right) \frac{C}{\Delta^{\prime}}
$$

From (A.6), this condition is satisfied on and below $I C C_{\text {priv }}$. Borrower expected utility $u$ is no less with public repayment and the ICC binding than with private repayment and the ICC not binding if

$$
\frac{h}{\Delta^{\prime}} \geq-\frac{1-\beta}{\beta}(2-p)+\frac{1-p}{p} \frac{C}{\Delta^{\prime}} .
$$

From (A.2), this inequality is satisfied on and, hence, above $I C C_{p u b}$. So public repayment is preferred by both MFIs and borrowers for parameters in B.

Next, consider $\left(C / \Delta^{\prime}, h / \Delta^{\prime}\right)$ in region C in Figure 2, where the ICC is binding with both repayment types. Here, MFIs get lower expected profit with public than with private repayment (viz., $\pi=$ $q p\left[(1-p) C-(2-p) \Delta^{\prime}\right]$, as compared to $\left.\pi=q p\left[C-(2-p) \Delta^{\prime}\right]\right)$. Borrowers, on the other hand, get higher expected utility (viz., $u=q[p h-(1-p) C]$, as compared to $u=q(p h-C)$ ). Public repayment yields the higher value for the Nash product exactly if

$$
\left[(1-p) C-(2-p) \Delta^{\prime}\right]^{\beta}[p h-(1-p) C]^{1-\beta}>\left[C-(2-p) \Delta^{\prime}\right]^{\beta}(p h-C)^{1-\beta} .
$$

Solving for $\beta$ yields the condition in the main text.

\section{Ability to repay}

For public repayment and the borrower's ICC not binding, from (A.1), the condition $h \geq 2\left(1+r^{*}\right)$ 
becomes

$$
[2(1-\beta)-p] \frac{h}{\Delta^{\prime}} \geq 2(1-\beta)(2-p)-2 \beta \frac{(1-p)^{2}}{p} \frac{C}{\Delta^{\prime}} .
$$

If repayment is public and the ICC is binding, the condition for ability to repay $h \geq 2\left(1+r^{*}\right)$ is

$$
\frac{h}{\Delta^{\prime}} \geq 2 \frac{1-p}{2-p} \frac{C}{\Delta^{\prime}}
$$

With individual repayment, borrowers are able to repay if

$$
\frac{h}{\Delta^{\prime}} \geq 2-p-\frac{\beta}{1-\beta} \frac{1-p}{p} \frac{C}{\Delta^{\prime}}
$$

when the ICC is not binding and

$$
\frac{h}{\Delta^{\prime}} \geq \frac{C}{\Delta^{\prime}}
$$

if the ICC is binding. Condition (14) implies that (A.11)-(A.13) are satisfied. Condition (14) further implies that (A.10) is satisfied for $\beta=0$. If condition (16) holds, then (A.10) is also satisfied for $\beta=1$ and, hence, for all $\beta$ in between. For the opposite case, (17) follows from solving (A.10) for $\beta$. 